\title{
Bringing Jesuit Bibliography into the Twenty-First Century: Boston College's New Sommervogel Online
}

\author{
Kasper Volk \\ Boston College \\ kasper.volk@bc.edu \\ Chris Staysniak \\ Boston College \\ christopher.staysniak@bc.edu
}

\begin{abstract}
This article introduces The Boston College Jesuit Bibliography: The New Sommervogel Online ( $N S O$ ), an ongoing project of the Institute for Advanced Jesuit Studies at Boston College in conjunction with the publisher Brill. Named for the famed nineteenthcentury Jesuit bibliographer Carlos Sommervogel, the NSo is the modern incarnation of a long and distinctive tradition of Jesuit bibliography. It harnesses the capabilities of the digital age to create a comprehensive, searchable, and open-access database cataloging thousands of Jesuit-themed books, book chapters, articles, and book reviews. By consolidating and organizing existing scholarship on the Society of Jesus, the new resource will provide a valuable service to scholars around the world and facilitate additional development within the already dynamic and rapidly expanding field of Jesuit studies.
\end{abstract}

\section{Keywords}

Pedro de Ribadeneyra - Philippe Algambe - Brothers De Backer - Auguste Carayon Carlos Sommervogel - László Polgár - Jesuit bibliography - digital humanities - New Sommervogel Online 
An exciting new project is in the works at Boston College, and it has the potential to revolutionize the field of Jesuit studies.

The Boston College Jesuit Bibliography: The New Sommervogel Online (NSO) (www.brill.com/nso) is a comprehensive, searchable, and open-access bibliography of all things Jesuit. A project of the Institute for Advanced Jesuit Studies (IAJS), the NSO uses an online platform developed by Brill Publishing to bring the venerable tradition of Jesuit bibliography into the digital age. Although the initial launch includes only materials published since 2011, coverage will eventually encompass the entire history of the Society, from 1540 to the present. The project is already global in its scope, thanks to the assistance of a growing network of scholars who contribute to the database from locations all around the world. Incorporating a wide variety of materials - including not just books and articles but also book chapters, book reviews, dissertations, and more-the NSO should soon become a premier resource for any scholar whose studies touch on the Jesuit order.

\section{A Burgeoning Field}

The $N S O$ responds to the needs of the emergent discipline of Jesuit studies. Of value to scholars engaged in a wide spectrum of academic pursuits and operating at all ability levels, the database will allow anyone interested in Jesuit themes to quickly orient him- or herself to the existing body of literature and keep abreast of subsequent developments within it. The bibliography will thus serve to consolidate and organize existing knowledge and catalyze additional research in an already rapidly expanding field.

Widespread scholarly interest in the Society is a relatively new phenomenon: as recently as the 1990s, most scholarship on the Jesuits was produced by the order's members and was intended primarily for internal consumption. The few works written by non-Jesuits often employed a crude dichotomy, casting its subjects as either "saints" or "devils incarnate" - a polarity of opinion that has existed in public perceptions of the Society since its sixteenth-century foundation. ${ }^{1}$ But in the past few years, Jesuit studies has undergone a remarkable transformation; the field's foremost scholar, John W. O'Malley, has gone so far as to call it a "revolution."2 One important aspect of the metamorphosis has been a change in authorship. The majority of scholars studying the Society no longer belong to it. In fact, many are not even Christian, let alone Roman Catholic. Equally crucial has been a shift in audience. Books about

1 John W. O'Malley, “The Historiography of the Society of Jesus: Where Does It Stand Today?, in O'Malley, Saints or Devils Incarnate?: Studies in Jesuit History (Leiden: Brill, 2013), 1-36, here 1.

2 John W. O'Malley, “Jesuit History: A Hot New Topic," America 192, no. 16 (May 9, 2005): 8-11, here 8. 
Jesuits now have general scholarly appeal and are being published by the most prestigious academic presses. Historical journals are brimming with articlelength studies of the Society, and within the past two years Brill has launched both this journal and a book series on Jesuit topics in order to capitalize on the avalanche of academic interest. ${ }^{3}$ The surge only gained momentum with the election of Pope Francis (b.1936), as the reign of the first Jesuit pontiff has sparked interest in the Society among popular circles as well. Jesuit studies is indeed, as O'Malley has noted, one of the "hottest" topics in early modern and modern history. ${ }^{4}$

There are several reasons for academia's sudden obsession with the Society of Jesus. One is that scholars have realized the value of Jesuit studies as a prism through which to view diverse facets of modern global history. To a degree that is unique among religious orders, the Jesuits pursued a breathtaking array of activities that went far beyond the educational endeavors for which they are best known. Historians and others are now investigating previously understudied aspects of the Jesuits' legacy, such as their involvement in mathematics, science, theater, dance, music, and colonial estate management, to name just a few. Furthermore, the extraordinary scope of the Jesuit missionary enterprisewhich ranged from the imperial courts of Beijing to the reducciones of Paraguayhas led the current generation of scholars to take an interest in those ventures as a lens through which to explore intercultural exchange. A prime example of this trend is the wealth of attention recently paid to the sixteenth- and seventeenthcentury Jesuit mission in China, led by Matteo Ricci (1552-1610) and his confrères. The China mission has generated a vibrant sub-category of Jesuit studies that has proven appealing to academic and popular audiences alike. ${ }^{5}$

To a degree that is only now being appreciated, the field of Jesuit studies intersects with topics and themes that lie at the very heart of our understanding of the modern world. From the Renaissance and the Reformation to the Scientific Revolution and the Enlightenment, from colonialism and imperialism to anti-modernism and totalitarianism, Jesuit studies touches upon them all. It is no wonder, then, the burgeoning of Jesuit-themed scholarship can be observed in a host of disciplines, including both historical specialty fields like

3 The Canadian religious publisher Novalis and the German publisher Schnell and Steiner have Jesuit book series as well.

4 O'Malley, "Jesuit History," 8.

5 See for example R. Po-Chia Hsia, A Jesuit in the Forbidden City: Matteo Ricci, 1552-161o (Oxford: Oxford University Press, 2010); Ana Carolina Hosne, The Jesuit Missions to China and Peru, 1570-1610: Expectations and Appraisals of Expansionism (New York: Routledge, 2013); Yu Liu, Harmonious Disagreement: Matteo Ricci and His Closest Chinese Friends (New York: Peter Lang, 2015); Qiong Zhang, Making the New World Their Own: Chinese Encounters with Jesuit Science in the Age of Discovery (Leiden: Brill, 2015). 
art history, military history, and the history of science, and non-historical disciplines, such as theology, literary studies, performance arts, international law, archaeology, and others. The plethora of analytical frameworks made available by such academic diversity has promoted fertile cross-pollination among the various fields, making Jesuit studies a shining exemplar of interdisciplinarity and helping it to flourish as a truly global scholarly enterprise.

The NSO will supply a vital foundation for the entire edifice. By creating a comprehensive bibliography, the project will help unify the field, prevent duplicated efforts, promote new connections, and point out directions for future research. And because its database is available in an online and readily searchable form, the $N S O$ will also showcase the enormous power of the digital humanities to enhance contemporary scholarship.

\section{A Distinctive Tradition}

The $N s o$ builds upon a long and well-established tradition of Jesuit bibliography. From its very foundation, the Society displayed a strong self-reflective impulse that gave rise to a robust historiographical and bibliographical sensibility. ${ }^{6}$ The Jesuits' concern for chronicling their own history was reflected in the actions of their first superiors general and led to the publication of three major bibliographies prior to the order's suppression in 1773 .

The Jesuits' historiographical legacy began with their founder himself, Ignatius of Loyola (c. 1491-1556). Ignatius insisted that his Society's business be conducted through frequent written communication, particularly between the provinces and Rome. ${ }^{7}$ His secretary, Juan Alfonso de Polanco (1516-77), kept a careful archive of all such correspondence. Polanco continued the practice while serving Diego Laínez (1512-65) and Francisco de Borja (1510-72), the order's next two superiors general, which resulted in a document collection dwarfing that of any other religious order. It also set a precedent for preserving and documenting the writings of the Society that has continued up to the present day.

The first actual bibliography to appear was the one compiled by Pedro de Ribadeneyra (1526-1611) in 1608. Published at the behest of Superior General Claudio Acquaviva $\left(1543^{-1615}\right),{ }^{8}$ the Illustrium scriptorum religionis Societatis

6 O'Malley, "Historiography of the Society," 3.

7 Ibid.

8 Paul Begheyn, Jesuit Books in the Dutch Republic and Its Generality Lands 1567-1773: A Bibliography (Leiden: Brill, 2014), 20. 
Iesu catalogus was intended more for the edification of its Jesuit readers than for historical or scholarly reference. ${ }^{9}$ In addition to its catalog of Jesuit writings, the volume included a lengthy preface, an ode to the Society, and a list of Jesuit martyrs. Authors were arranged alphabetically by first name, and bibliographical notes emphasized the virtues of the listed writings rather than providing a more scholarly analysis. Furthermore, the Catalogus did not aspire to be comprehensive. It included only selected writings, those which were deemed most valuable to its Jesuit audience. It was, in short, a product of its time-still far from a modern bibliography, but an important step in that direction.

An updated version of Ribadeneyra's bibliography, entitled Bibliotheca scriptorum Societatis Iesu, was released in 1643 in honor of the Society's centenary. ${ }^{10}$ Its editor was the Belgian Jesuit Philippe Algambe (1592-1652), who was assisted in his labor by another notable Jesuit scholar, Jean Bolland (15961665). ${ }^{11}$ Algambe's version was a marked improvement over its predecessor. It added a number of authors - including ex-Jesuits—and provided much more extensive bibliographical information. ${ }^{12}$ It was also more comprehensive: Algambe's goal had been to include all published Jesuit writings as well as notable manuscripts.

The last great pre-suppression bibliography was published by Nathanael Southwell (1598-1676), an English Jesuit, in 1676. Checking in at over one thousand pages, Southwell's update of Ribadeneyra and Algambe's work was another significant step forward for Jesuit bibliography. ${ }^{13}$ It added new writers and new titles (including translations and unpublished manuscripts), contained updated and improved bibliographical information, and even included books that had been placed on the Index (of forbidden books). ${ }^{14}$ The lastnamed change in particular is indicative of a growing historical awareness among Jesuit bibliographers. ${ }^{15}$

Unfortunately, the development of Jesuit bibliography was soon brought to an abrupt (albeit temporary) halt. The Jesuit order itself was disbanded, first in several countries and then, in 1773, throughout the world. Although some

Robert Danieluk, La Bibliothèque de Carlos Sommervogel: Le Sommet de l'oeuvre bibliographique de la Compagnie de Jésus (1890-1932) (Rome: Institutum Historicum S.I., 2006), 63-64.

10 Begheyn, Jesuit Books, 20-21.

11 Danieluk, Bibliothèque de Carlos Sommervogel, 75 .

12 Ibid., 76-77.

13 Begheyn, Jesuit Books, 21.

14 Danieluk, Bibliothèque de Carlos Sommervogel, 84-89.

15 Ibid., 89. 
bibliographical work continued, the environment was obviously not conducive to such efforts. But like the Society of Jesus as a whole, the Jesuit bibliographical tradition would soon be reborn, emerging from its period of dormancy stronger than ever.

\section{A New Era}

The Society of Jesus was reestablished in 1814 after forty-one years of official nonexistence. As the Society was rebuilt, efforts were made to resurrect its bibliographical tradition as well. The aim, however, was not simply to restore, but to renew. Nineteenth-century Jesuit scholars brought the bibliography of their order into the modern era and imbued it with the new historical sensibility of their age.

The restoration of Jesuit bibliography was set in motion in 1829 , when the Twenty-First General Congregation decided that a new bibliographical project should be undertaken and directed the provincial superiors to begin collecting relevant materials. ${ }^{16}$ Superior General Jan Philip Roothaan (1785-1853) reiterated that order in 1844 and assigned the task of compiling the new bibliography to Paulo Beorchia $\left(1795^{-1859)} \cdot{ }^{17}\right.$ Unfortunately, the events of 1848 intervened. The revolution in Rome resulted in the expulsion of the Jesuits from the city, and many of Beorchia's notes were lost in the confusion. As a result, his bibliography was never published. However, the general congregation's order of 1829 did produce many partial bibliographies, which would prove useful to Beorchia's successors.

The task of compiling a new Jesuit bibliography fell to Augustin De Backer (1809-73), who was aided by his brother Aloïs (1823-83). Conducting their research in Belgian, French, and Italian libraries and drawing upon the efforts of the Jesuit provincials, the De Backers published the first volume of their Bibliothèque des écrivains de la Compagnie de Jésus in $1853 .{ }^{18}$ The seventh and final installment came eight years later, in $1861 .{ }^{19}$ Although the De Backers emphasized the continuity of their project with the work of their presuppression predecessors, their bibliography was notably modern in many respects. ${ }^{20}$ The brothers elected to publish their work in French rather than Latin, and they provided titles in their original language rather than translating

\footnotetext{
16 O'Malley, "Historiography of the Society," 15.

17 Danieluk, Bibliothèque de Carlos Sommervogel, 112-16.

18 Ibid., 124-25.

19 Ibid., 129.

20 Ibid., 124-25.
} 
them. Although they included short biographical notes on each author, they condensed that section and instead expanded the bibliographical information provided, including subsequent editions and translations of each listed work. They also offered extensive commentary on the apologetics and controversies occasioned by notable entries, in keeping with the new historiographical sensibility of their era.

The Bibliothèque des écrivains de la Compagnie de Jésus was from the beginning a collaborative project. When the De Backers began publishing the bibliography, they asked that its readers inform them of any errors that should be corrected or additions that should be made. ${ }^{21}$ One reader in particular took them up on that request, editing each volume carefully and compiling a massive list of revisions. ${ }^{22}$ That reader was Carlos Sommervogel (1834-1902), the De Backers' eventual successor and the namesake of the new IAJs project.

Carlos Sommervogel is rightly remembered as the foremost Jesuit bibliographer, for it is his work that would bring the field to its pinnacle at the end of the nineteenth century. Born in Strasbourg in 1834, he entered the novitiate at Issenheim in 1853 and completed his literary studies at Saint-Acheul, in Amiens, soon after. ${ }^{23} \mathrm{He}$ was then sent to the College of the Immaculate Conception in Paris, where he served as assistant prefect of discipline and sublibrarian from 1856 to 1865 . It was during these years that he began his editing of the De Backers' work, eventually producing an eight-hundred-page manuscript that contained ten thousand new and revised entries.

From the get-go, Augustin De Backer considered Sommervogel a worthy collaborator, and he soon determined to bring the Alsatian Jesuit onboard as coauthor for the second edition of the Bibliothèque. This was only fair, as the publication of a second edition had been Sommervogel's idea in the first place. ${ }^{24}$ Initially, the De Backers had intended simply to issue a supplemental volume to the first edition. But in 1862, Sommervogel suggested a new edition, and given the number of additions and revisions he had compiled, Augustin De Backer agreed that this was the best course. The first volume of the second edition, which contained 4,200 entries, appeared in 1869; the second and third followed in 1872 and $1876 .{ }^{25}$

\footnotetext{
21 Ibid., 129.

22 John Hungerford Pollen, "Distinguished Jesuits," in The Catholic Encyclopedia, vol. 14 (New York: Robert Appleton, 1912), Catholic Online, http://www.catholic.org/encyclopedia/ view.php?id=6315.

23 Ibid.

24 Danieluk, Bibliothèque de Carlos Sommervogel, 129-30.

25 Ibid., 131-33.
} 
Massive though it was, the Bibliothèque had a notable limitation. Like its predecessors, the bibliography cataloged only works written by Jesuits. Works about Jesuits were left out, and it was this lacuna that Auguste Carayon (1813-74) worked to fill. ${ }^{26}$ Seeking to address what he perceived to be a disregard for religious - and especially Jesuit-historiography, the French Jesuit published the first historical bibliography of the Society, entitled Bibliographie historique de la Compagnie de Jésus, in 1864. The volume included works by non-Jesuit authors as well as the writings of Jesuits, and unlike previous bibliographies, was organized by subject rather than by author. Carayon seems to have envisioned his work as a complement to existing bibliographies, as he consulted extensively with the De Backers, Sommervogel, and the Bollandists while compiling it. ${ }^{27}$

Carayon's labor set the stage for Sommervogel's masterwork: the third edition of the Bibliothèque de la Compagnie de Jésus, which the Jesuit scholar Robert Danieluk justifiably names the "summit" of Jesuit bibliography. The third edition dropped "writings" from its title because it was Sommervogel's intent to take up the mantle of both the De Backers and Carayon. The new Bibliothèque was to be published in two parts, the first an updated and expanded version of its previous edition and the second a revision of the Bibliographie. ${ }^{28}$ Unfortunately, Sommervogel passed away before bringing his full vision to fruition. He was "only" able to finish the first part, consisting of nine volumes containing 9,000 pages and an estimated 150,000 entries. ${ }^{29}$ His work was, however, completed posthumously, albeit in somewhat abbreviated form. Spanning over three and a half centuries of Jesuit history, from 1540 to 1900, Sommervogel's Bibliothèque remains the most comprehensive Jesuit bibliography in existence and is an achievement of truly monumental proportions.

Sommervogel's crowning labor began in earnest in 1885 , when he was appointed the De Backers' official successor and sent to Leuven. ${ }^{30}$ The first volume of his Bibliothèque appeared in 1890, the ninth in 1900. As had been the case with the second edition, entries were divided among the volumes alphabetically by author, with part of the eighth and all of the ninth tomes consisting of supplemental material. Sommervogel also continued the practices of including short biographical notes about the authors, listing subsequent editions and

\footnotetext{
26 Ibid., 134-35.

27 Ibid., 136-37.

28 Pollen, "Distinguished Jesuits."

29 Theodore A. Besterman, A World Bibliography of Bibliographies and of Bibliographical Catalogues, Calendars, Abstracts, Digests, Indexes, and the Like, $4^{\text {th }}$ ed. (Lausanne: Societas Bibliographica, 1965-66), 3261-62.

Pollen, "Distinguished Jesuits."
} 
translations, and occasionally commenting on connections between books or arguments. ${ }^{31}$ His detailed entries provided all of the data one would expect in a modern bibliography, including editors, publication data, formats, and numbers of pages. Titles in unfamiliar languages were given in Latin.

The ninth through twelfth volumes consisted of indexes, supplemental materials and corrections, and a historical bibliography. The last volume edited by Sommervogel himself was volume nine, which included an index of authors listed by nationality. ${ }^{32}$ Volume ten, edited by Pierre Bliard (1852-1928), appeared in 1909—-seven years after Sommervogel's death—and provided an index by subject; its five major headings were theology, jurisprudence, arts and sciences, belles-lettres, and geography and history. ${ }^{33}$ Bliard also edited volume eleven, the long-anticipated historical bibliography, which did not appear until $193^{2.34}$ The final volume, containing supplements and corrections, was published in five parts between 1911 and 1930. Its editors were Ernest Rivière (18541919) and Ferdinand Cavallera (1875-1954).

The publication of Sommervogel's Bibliothèque was a signal achievement. It marked the culmination of an initiative that had been launched nearly three quarters of century earlier and had incorporated the labor of three generations of scholars. The Jesuit bibliographical tradition had been not just restored but renewed - updated and expanded in accordance with the historical sensibilities and enhanced capabilities of a new century. The NSo is proud to bear Sommervogel's name and continue his legacy.

\section{The Twentieth Century and Beyond}

Following Sommervogel's death, Jesuit bibliography entered a rather arid phase. Although several attempts were made to carry on the master's work, it was over fifty years before a full-fledged successor emerged. When that occurred, it was not without a significant transformation, as the focus of Jesuit bibliography had shifted from Jesuit writings to Jesuit history.

The first attempt to continue Sommervogel's labor was made by the Moniteur bibliographique de la Compagnie de Jésus, a periodical bibliographical review initially published as a supplement to Études. ${ }^{35}$ The Moniteur actually began

\footnotetext{
31 Danieluk, Bibliothèque de Carlos Sommervogel, 183.

32 Ibid., 191-92.

33 Ibid., 186.

34 Ibid., 208-10.

35 Ibid., 217-18.
} 
publication in 1889, with Sommervogel himself serving as its editor from 1895 until 1901. Its goals were to provide up-to-date bibliographical information for use within the Society and to facilitate the compilation of subsequent editions of the Bibliothèque. Embodying Sommervogel's expansive vision, the review listed both works by and works about Jesuits, including those written by nonmembers of the order. ${ }^{36}$ The first run of the publication, from 1889 to 1901 , provided bibliographical coverage of the years that had elapsed since Sommervogel began work on his bibliography. ${ }^{37}$ The second run, from 1908 to 1928 , extended that coverage to 1914 .

The Moniteur had no immediate successors, creating a significant gap in the bibliographical record and leading to a renewed separation of Jesuit writings from Jesuit history. The former strand was picked up by Jesús Juamblex (18951960), the first editor of the Index bibliographicus Societatis Iesu. ${ }^{38}$ Published from 1937 through 1977 , the Index was intended to replace the defunct Moniteur and pave the way for a new edition of Sommervogel's Bibliothèque. Its twenty volumes were organized by subject, in accordance with the schema established by Bliard. The Index was more narrowly focused than its immediate predecessors, however, as it once again covered only those works that had been written by Jesuits, excluding those that were merely about them.

The other strand of Jesuit bibliography was left to the Archivum historicum Societatis Iesu (AHSI), the semi-annual journal of the Jesuit Historical Institute (IHSI). Established in 1932, the AHSI-like its parent organization—reflected the growing historical self-awareness of the Jesuit order. Beginning in 1933, the AHSI published a series of more-or-less annual bibliographies that were emblematic of that shift. ${ }^{39}$ The journal's editor, Edmond Lamalle (1900-89), introduced an updated and more historically-minded classification system, dividing his listings into three broad categories: general history, local history, and history of persons. He also provided each entry with a label identifying the subject of the piece. More importantly, his reviews represented a shift in the bibliographical balance between Jesuit writings and Jesuit history. Whereas in the nineteenth century, historical bibliographies were treated as something of an afterthought, the AHSI catalogs were now on equal footing with the more traditional listings of the Index. The evolution reflected a long-term rethinking of the purpose of Jesuit bibliography and was a trend that would be continued

36 László Szilás, "László Polgár, S.J. (1920-2001)," Archivum historicum Societatis Iesu 70, no. 140 (2001): 613-18, here 616.

38 Ibid., 224-26.

39 Ibid., 229-30. 
by Sommervogel's true twentieth-century heir, the Hungarian Jesuit László Polgár (1920-2001).

Polgár's story is an interesting one. Born in the village of Németker in 1920, he entered the order in Budapest in $1938 .{ }^{40}$ Although he was able to pursue his normal course of studies during World War II, fears spawned by the deepening Cold War led his superiors to determine that he, like other Hungarian Jesuit scholastics, should be sent abroad. After a secret ordination ceremony in 1949, Polgár fled to Rome, and was appointed to the IHSI the following year. There, he began a half century of bibliographical work. Although initially appointed as the institute's Hungarian historian and bibliographer, Polgár soon took over Lamalle's duties with $A H S I$ and published the first of his fifty annual bibliographies in $1952 .{ }^{41}$ Bothered by the gap in historiographical coverage between 1914 (the last year covered by the Moniteur) and 1931 (the first covered by AHSI), he also decided - in 1965 - to issue a supplemental volume containing data for the missing years. ${ }^{42}$ Soon, his project grew much larger. Finding a number of errors and notable omissions in both the later run of the Moniteur and the earlier AHSI bibliographies, Polgár began work on a bibliography that would cover the entire twentieth century.

The result was the Bibliographie sur l'histoire de la Compagnie de Jésus 19o11980, a massive six-volume work published between 1981 and 1990. ${ }^{43}$ Expanding upon the system laid out by Lamalle, Polgár divided his bibliography into three parts. The first, contained in volume one, dealt with the general history of the Society. The second covered local Jesuit history, with one volume devoted to Europe and a second devoted to the rest of the world. The final three volumes, dealing with individual Jesuits, were organized alphabetically by person and included after each letter section a supplemental list of Jesuits mentioned in various reference works. All told, part three included 3,805 Jesuits to whom bibliographical entries were connected and an additional 3,325 members of the order who were merely named. The immense scope of Polgár's project is reinforced by a glance at the total number of entries: 45,000 in the Bibliographie itself and an additional 20,000 in the annual bibliographies issued for the years 1981 through 2000.

In addition to its size, Polgár's bibliography is notable for its thoroughness and its meticulous attention to detail. ${ }^{44}$ The Hungarian priest travelled extensively in

\footnotetext{
$40 \quad$ Szilás, "László Polgár," 613-14.

41 Danieluk, Bibliothèque de Carlos Sommervogel, 230.

42 Szilás, "László Polgár," 616.

43 Ibid., 616-17.

44 Ibid., $617-18$.
} 
order to collect his materials and developed an international network of "cooperators" who notified him of items that he might otherwise have missed. His work is renowned for its accuracy in both the bibliographical data it provides and in its spelling, which is no small matter considering the number of languages involved. Remarkably, Polgár accomplished this feat without ever touching a computer: he kept track of prodigious quantities of data using only a traditional file card system and a sharp mind.

One of the more significant editorial choices that Polgár made was to focus on Jesuit history rather than Jesuit writings. His decision was indicative of the changing nature of Jesuit bibliography: once produced primarily for internal consumption, it is now of interest to a wide and growing number of non-Jesuit scholars around the world.

The twentieth century, like the nineteenth, was a time of both continuity and change in the field of Jesuit bibliography. In each period, a figure emerged who was able not only to build upon the legacy of his predecessors but also to modernize it in response to the evolving circumstances of his day. Following in the footsteps of both Sommervogel and Polgár, the $N S O$ aspires to play a similar role in a new millennium.

\section{A Jesuit Bibliography for the Digital Age}

The Nso builds upon and will ultimately transcend the work of its predecessors. Using the new tools of the digital humanities, it is bringing the rich tradition of Jesuit bibliography into the twenty-first century. In keeping with the most recent developments in the field of Jesuit studies, the new bibliography is primarily historical in nature (systematically cataloging items that are about rather than by Jesuits) and focuses on academic and peer-reviewed works. The result is a resource that will prove to be of great value to the scholarly community, the Jesuit order, and perhaps even a portion of the general public as well.

The Nso has several advantages over previous bibliographies. First and foremost, it is digital. Print bibliographies take an immense amount of labor to prepare and are often outdated by the time they appear. Additions or corrections take years to address, as such updates generally have to wait for a new edition or at least until a supplementary bibliography can be prepared. The NSO may be just as laborious initially, but it is much more flexible in the long run. Because it uses an online platform, it can publish data as it is collected and expand its coverage incrementally. The database can also be continuously updated as new information becomes available. 
Another advantage of the digital format is its searchability. Users of the database can quickly find what they are looking for using a Google-style keyword search for any term that appears in the bibliographic records. The Nso capitalizes on that capability through its most innovative feature: the addition of up to four subject fields to each entry. Whenever applicable, labels identifying the person, place, time period, and subject with which an item deals have been added to its record, which enables researchers to locate materials using those terms as well. Such a robust search function is obviously impossible to achieve with a standard bibliography. The closest approximation that can be made is to include one or more indexes, the publication of which was once a highly valuable feature but has now been rendered obsolete by the digital revolution. Libraries have long since switched from print to digital catalogs. It is high time that Jesuit bibliography follows suit.

A third benefit of the NSo's digital format is that it makes the bibliography much more accessible. A massive, multi-volume catalog such as those produced by Sommervogel or Polgár is an expensive investment that many libraries cannot afford to make. Even fewer individual scholars could justify such a purchase. But digital databases are readily available to anyone with a computer and a subscription. And in the case of the Nso, even the latter limitation does not apply: thanks to the generous support of Boston College, the bibliography is a fully open-access resource.

The $N S O$ will also be more comprehensive than its predecessors. Its listings include books, book chapters, journal articles, book reviews, and dissertations, as well as a few other types of materials. Relevant books are found primarily through methodical searches of the World Library Catalog (WorldCat), while journal articles and book reviews are discovered by systematically scanning over 1,300 periodicals - a number that will increase over time. The journals covered are drawn from a wide array of disciplines and published in some twenty-six languages, a reflection of the diversity and global appeal of Jesuit studies. The $N S O$ staff also peruses existing bibliographies to ensure that nothing has been missed and that the database is as comprehensive as possible. This means that the NSO will eventually incorporate all of the bibliographies that preceded it, thus making the fruits of their authors' labor available in a format appropriate for a new digital age.

The inclusion of book reviews is a particularly innovative feature of the NSO and is unique to that database. It allows users to quickly and easily obtain scholarly distillations of monographs that pique their interest, are hard to find, or are printed in languages unfamiliar to them. In addition, users can quickly estimate the impact of a given work based on the number of times it was reviewed in major journals. In some cases, book reviews are even linked to the record of the book itself, a handy feature of the Brill platform. 
Following Polgár, the Nso focuses primarily on historical bibliography. It systematically catalogs only works about Jesuits, although a few works that are simply by Jesuits find their way into the database as well. The writings of Jesuits who are frequently studied in their own right-such as Pierre Teilhard de Chardin (1881-1955), for example - are usually included, on the grounds that such texts can be considered valuable primary sources. But no effort is currently being made to capture all Jesuit writings, for a couple of reasons. First, while the historical bibliography of the Society of Jesus has a wide and growing scholarly appeal, the bibliography of Jesuit writings is of greater interest to the order itself. That audience is considerably smaller, perhaps accounting for the fact that there has been no comprehensive index of Jesuit writings since the cessation of the Index in $1977 .{ }^{45}$ Second, there is a practical consideration: the NSO is already such an immense undertaking that cataloging works by Jesuits as well as about them is simply not feasible. At least not at this time-reuniting the two strands of Jesuit bibliography remains a long-term goal of the project.

For reasons similar to those just mentioned, the NSO is systematically scanning only academic and quasi-academic periodicals. Provincial newsletters, popular magazines, and the like are being left out for now, although there are hopes of including them at a later date.

So far, the NSo team has collected and edited complete data for the years 2011-13. Over that time span, the bibliographical "take" has been approximately 1,200 citations per year. Given that Polgár's annual bibliographies for 1981-2000 included approximately 1,000 entries per year, the 2011-13 average seems to be a reasonable baseline. As the collection efforts focus on progressively earlier years, that figure is likely to decrease, as the volume of published material declines. However, there can be little doubt that the combined bibliography for the entire twentieth century and the twenty-first century thus far will include well in excess of 100,00o entries when complete. Of course, it will likely be a decade or more before that vision is realized, and there will still remain the small matter of incorporating Sommervogel's 150,000-entry Bibliothèque. The Nso is a very long-term project. But its value to the scholarly community is already apparent and will only increase as the bibliography grows.

\section{Nuts and Bolts}

The collection and editing of bibliographical data for the NSO is no small task. The bulk of the collection is performed by the project's staff at the IAJs, which 
consists of four assistant editors (including the authors of this article) and an editor-in-chief (Robert Maryks, who is also the editor-in-chief of this journal). They are greatly assisted by a network of over sixty correspondents who contribute to the project from around the globe. The editorial team reviews all collected data for accuracy and completeness, adds the custom subject fields mentioned above, and then submits the resulting data set to Brill so it can be uploaded onto the $N S O$ platform. The bibliographical data is being collected in three-year increments, working backwards from the present day, and the collection is currently proceeding at a rate of approximately five years checked per calendar year of work.

Data collection falls into two main categories: books and articles. The primary tool used to identify Jesuit-themed books is WorldCat, recommended by the Boston College research librarians as the single most comprehensive resource available for the purpose. While no single catalog can capture every existing record, WorldCat comes closer than any other, having already integrated over two billion entries from major library holdings across the globe; in fact, the NSo staff found that all of the major library catalogs it considered checking were already included in the WorldCat database. Relying on a single, aggregated resource also has a couple of distinct advantages. One is that it avoids the potential for confusion and overlap that would come with searching multiple catalogs. Another is that it is more efficient, offering the maximal return on temporal (and therefore monetary) investment.

The Nso staff performs their searches of WorldCat in a methodical manner. Progressing year by year, they run keyword searches not just for the term "Jesuit" (and its non-English variations) but also for the names of well-known Jesuits who are not always listed as such (e.g., Karl Rahner [1904-84] or Teilhard de Chardin) and for a select number of additional subject terms as well. The list of additional names and terms has coalesced through trial and error and is continuously being refined.

Jesuit-themed articles are discovered through a much different process. When the NSO was getting off the ground, the staff compiled a list of over 1,60o journals that are known to have published articles about Jesuits at some time, using existing bibliographies as a reference. As the project progresses, the list is continually updated. Journals thus identified are then systematically scanned, year by year, to identify any articles or reviews related to the Society of Jesus. The bibliographical data for such articles is then captured for inclusion in the Nso database.

At present, about 1,300 journals are being checked. Twenty-six languages are represented, although the majority of articles found are printed in English, Spanish, Italian, Portuguese, or French. As the project grows, its staff hopes to 
be able to expand its coverage, in terms of both the number of periodicals scanned and their linguistic and geographical scope.

To assist in the enormous task of scanning many hundreds of periodicals, the editorial team has recruited a global network of "correspondents" scholarly volunteers who assist the project by perusing journals and submitting any relevant bibliographical data they find using an online form. The network currently consists of over sixty active correspondents hailing from twenty-two nations on five continents and speaking fifteen different languages, and nearly one hundred scholars have contributed to the project during its first two years of existence. The global collaboration engendered by the $N S O$ is perhaps its most notable and inspiring feature-one that is in keeping with the spirit of Sommervogel's original work and that illustrates the enormous potential of the digital humanities. The correspondents' network has also been of enormous practical value to the project, as it not only eases the burden on the editorial staff but also enables coverage of journals that are unavailable at Boston College or are printed in languages with which the Nso staff is unfamiliar. ${ }^{46}$

In the process of identifying both books and articles worthy of inclusion, a question inevitably arises: what counts as "relevant?" Although the answer to this question is inherently subjective, the Nso team has established certain guidelines. In general, an item is considered relevant if the Jesuit or Jesuit topic addressed is central enough to the work to be mentioned in its title, abstract, introduction or conclusion. In other words, the mere passing mention of a Society member, the order itself, or a related topic is not enough for a book or article to be included in the bibliography.

The data collected includes a wealth of bibliographical information. Aside from such standard items as titles, authors, editors, issue and page numbers, and publication data, the Nso provides book series information, numbers of pages, and publication languages. It also supplies ISBNS, ISSNS, and DOIs, elements that are particularly important for tracking down digital versions of resources. The ability to include virtually all available data, without worrying about the sheer size of the resulting bibliography, is one of the greatest advantages of the Nso's digital format.

Two additional elements of the Nso's citations are particularly noteworthy. The first is the inclusion of abstracts. Although the $N s o$ team does not generate such descriptions - the time investment would be prohibitive-it does include any abstracts supplied by publishers or other reputable sources. This makes the $N s o$, in essence, an annotated bibliography. The second element of

46 If you would like to get involved with the $N s o$, please contact Kasper Volk at volkkasp@ gmail.com. 
note is the provision of external links to items whenever such links are available. In some cases, an institutional log-in is required (e.g., for items on JSTOR), and in other cases, access must be purchased from a publisher. But a surprising number of items are freely available, in which case Nso users can navigate directly to those resources. For print books, which are usually not accessible online, the link points instead to the item's WorldCat record, to assist the user in locating a copy of the work in question. The inclusion of abstracts and direct links to cited items are features unique to the Nso.

But the most innovative feature of the project is its addition of four custom subject fields: "when," "where," "who," and "what." The "when" field specifies the century or centuries with which an item primarily deals. For example, a book on the suppression and restoration of the Jesuits would receive the label " $18^{\text {th }}-19^{\text {th }}$ century." Entries not associated with any particular time period, such as some general works on Ignatian spirituality, receive no "when" designation.

The "where" field identifies the geographic location with which a cited work is associated, following the WorldCat convention of listing the continent first and then progressing downward to the smallest relevant locality. A journal article on Jesuits in Paris, for instance, would be labelled "Europe - France Paris." In all cases, geographic designations are generated based on current state names and boundaries.

Logically enough, the "who" field tells which Jesuit or Jesuits a work is principally about. Not every Jesuit named in an article is listed: only those whom an article is substantially about make the cut, in accordance with the guidelines on relevancy listed above. The designations match those given by the Library of Congress Authorities, except for a small number that have been modified in the interest of accuracy. The standard format lists the subject's last name, first name, and years of birth and death. As an example, an article on Francis Xavier (1506-65) would be labelled "Francis Xavier, Saint, $1506-1565$." As the NSO is a bibliography on Jesuits specifically, only members of the order are included in its subject headings.

Finally, the "what" field lists the subject of a book or article. The classification system is one that has been developed by the Nso editorial staff, based on the subject listings of previous historical bibliographies, especially that of Polgár. Only Jesuit-related topics are included. An article about Jesuit higher education in Goa, for instance, would be listed under the category "Jesuits Education - Universities."

The addition of these four subject fields is one of the key features of the Nso. Having such a classification system in place makes it possible for users of the bibliography to search it in the same way they would search a library catalog. Building upon the categorization and indexing schemes of Polgár, Lamalle, 
and Carayon, it is yet another way in which the NSo is bringing Jesuit bibliography into the twenty-first century.

Once the data for a given period has been fully collected, edited, and classified, it is sent to Brill. The Leiden-based publishing house-selected for its technical expertise and its reputation in the field of Jesuit studies-has partnered with the IAJS and Boston College to provide an online platform for the Nso. The initial launch includes data for the years 2011 through 2013, consisting of approximately 3,600 citations, with data for 2006-10 to follow.

\section{State of the Field}

The citations collected for the Nso provide more than just a bibliographical resource. By analyzing the data in aggregate, it is possible to attain a snapshot of the current state of Jesuit studies. A look at the people, geographic regions, and time periods that were most studied over the past few years reveals the topics that are currently trending and suggests possible directions for future research. It also provides a glimpse into the sort of data contained within the Nso database.

The foundation of the Society is a topic of perennial interest. Not surprisingly, Ignatius of Loyola is a dominant figure: between the years 2011 and 2013, he was mentioned in 153 citations, making him the most frequently referenced Jesuit. Borja, another early leader of the order, garnered 70 references, placing him among the top six. Ignatius, of course, is studied not only as a historical figure but in the context of Jesuit spirituality, making him the subject of a great number of Jesuit writings. Such studies are, however, of greater interest to scholars within the Jesuit community than outside of it, as seems to be true for the subject of Jesuit origins in general.

Another mainstay of Jesuit studies is Jesuit theology. A quartet of twentiethcentury theologians-Bernard Lonergan (1904-84), Hans Urs von Balthasar (1905-88), ${ }^{47}$ Karl Rahner, and Henri de Lubac (1896-1991) — are among the seven Jesuits most frequently mentioned. Featuring not just as figures of historical interest but as active dialog partners, these four men continue to exercise enormous theological and philosophical influence, both in Catholic circles and beyond. Their presence in primers of post-conciliar theology is all but mandatory, and new editions of their works continue to appear on a regular

47 Although von Balthasar left the order later in life, he and other ex-Jesuits are still included in the Nso bibliography. 
basis. Jesuit theology has long been and will likely remain one of the most vibrant sub-fields of Jesuit studies.

A newer and fresher variation on the topic is liberation theology. The two dominant figures here are Ignacio Ellacuría (1930-89), who was one of the Jesuits martyred in El Salvador in 1989, and Jon Sobrino (b.1938), who continues his work at the University of Central America. As 2014 marked the twentyfifth anniversary of the UCA massacre, interest in liberation theology has recently spiked. ${ }^{48}$ But it has long been a subject of considerable interest, lying as it does at the intersection of theology and social history.

Another thinker who has recently inspired a surge of interest is the sixteenthcentury Scholastic Francisco Suárez (1548-1617). Although Suárez has long been a mainstay of Continental scholarship, it is only in the past few years that he has been discovered by English-speaking authors. This has led to a flurry of works engaging with the philosopher in terms of both his thought itself and his place in intellectual history. He was among the top ten most frequently referenced Jesuits for 2011-13, and the Suárezian trend is still going strong. ${ }^{49}$

Then there is Pope Francis. The election of the first Jesuit pontiff set off a veritable avalanche of scholarly and popular literature. The leading edge of the trend shows up in the Nso's initial data set: there were fifty-seven Francis-themed items in 2013 alone, enough to make him the seventh-mostmentioned Jesuit for the entire three-year period. And the steady stream of commentaries, biographies, interviews, and collected sermons shows no signs of stopping. Uniquely within the field of Jesuit studies, Francis's papacy has enormous popular appeal, a point that is reflected in the diversity of the publishers climbing on the bandwagon. Catholic presses like Loyola, Paulist, Ignatius, and Orbis have led the way, ${ }^{50}$ but popular presses such as Bloomsbury, Viking, HarperCollins, and Rowman \& Littlefield are riding the wave as well. ${ }^{51}$

48 See, for example, Robert Lassalle-Klein, Blood and Ink: Ignacio Ellacuría, Jon Sobrino, and the Jesuit Martyrs of the University of Central America (Maryknoll, NY: Orbis, 2014) and J. Matthew Ashley, Kevin F. Burke, and Rodolfo Cardenal, eds., A Grammar of Justice: The Legacy of Ignacio Ellacuría (Maryknoll, NY: Orbis, 2014).

49 Notable works for 2014 include Victor M. Salas and Robert L. Fastiggi, eds., A Companion to Francisco Suárez (Leiden: Brill, 2014) and Lukáš Novák, ed., Suárez’s Metaphysics in Its Historical and Systematic Context (Berlin: De Gruyter, 2014).

5o Alejandro Bermudez, Pope Francis: Our Brother, Our Friend; Personal Recollections about the Man Who Became Pope (San Francisco: Ignatius, 2013); Pope Francis, The Church of Mercy (Chicago: Loyola, 2014); Massimo Faggioli, Pope Francis Tradition in Transition (New York: Paulist, 2015); Pope Francis, Morning Homilies (Maryknoll, NY: Orbis, 2015).

51 Paul Vallely, Pope Francis: Untying the Knots (London: Bloomsbury, 2013); Pope Francis, A Big Heart Open to God: A Conversation with Pope Francis (New York: HarperCollins, 2013); 
The entire field of Jesuit studies has benefitted from the "Francis effect," as interest in the Society has surged. ${ }^{52}$

If Francis is the rock star of Jesuit studies, the hottest scholarly topic is intercultural exchange. The region that has received the most attention so far is China. The leader of the Jesuits' sixteenth-century mission there, Matteo Ricci, was featured in 136 citations from 2011-13, which makes him —at least in that regard - second only to Ignatius himself. A noted critical biography of Ricci, Hsia's A Jesuit in the Forbidden City, was reviewed twenty-three times over that period, three times as often as any other book. Japan has received its share of attention as well. The leader of that mission, Francis Xavier, was one of the top thirteen most-referenced Jesuits in the initial data set. So too was António Vieira (1608-97), the seventeenth-century philosopher, orator, and missionary, who was associated with the Jesuit mission in Brazil. The recent attention paid to these men and their work reflects a growing appreciation of the role played by Jesuits in forging connections between Europe and the rest of the world.

The Jesuits' efforts among-and impact upon-the Guaraní Indians of South America is another subject of particular interest. The 2011-13 bibliography includes more than sixty books and articles on the reducciones of Paraguay, just slightly fewer than were published on Japan. And the body of literature continues to grow. Recent treatments of the subject approach it from diverse perspectives, including those of economic history, ${ }^{53}$ social history, ${ }^{54}$ and the history of science. ${ }^{55}$ Because the Jesuit missionary enterprise is a nexus of so many critical issues, it has become a highly valued lens through which to examine European encounters with the non-European world.

Awareness of the importance of the Society in the context of European colonialism has spread to more general studies of the subject as well. Several recent monographs on imperialism and the indigenous response

Robert Blair Kaiser, Inside the Jesuits: How Pope Francis is Changing the Church and the World (Lanham, MD: Rowman \& Littlefield, 2014); Gary Wills, The Future of the Catholic Church with Pope Francis (New York: Viking, 2015).

$5^{2}$ Witness John W. O'Malley, The Jesuits: A History from Ignatius to the Present (Lanham, MD: Rowman \& Littlefield, 2014), which features a picture of Francis on its cover.

53 Julia J. S. Sarreal, The Guaraní and their Missions: A Socioeconomic History (Stanford, CA: Stanford University Press, 2014).

54 Robert H. Jackson, Demographic Change and Ethnic Survival among the Sedentary Populations on the Jesuit Mission Frontiers of Spanish South America, 16o9-1803: The Formation and Persistence of Mission Communities in a Comparative Context (Leiden: Brill, 2015).

55 Miguel de Asúa, Science in the Vanished Arcadia: Knowledge of Nature in the Jesuit Missions of Paraguay and Río de la Plata (Leiden: Brill, 2014). 
ascribe a prominent role to Jesuit missionaries. ${ }^{56}$ The incorporation of Jesuit studies into mainstream scholarly discourse is yet another sign of the field's flourishing.

The exploration of Jesuit contributions to science is another rapidly expanding endeavor. Between 2011 and 2013, there appeared nearly two hundred books, articles, and reviews addressing the subject, and a recent spate of monographs suggests that growth in the field has only just begun. ${ }^{57}$ Spanning the order's nearly five-century history and investigating topics ranging from alchemy and the occult to mathematics and meteorology, these studies reveal the integral role members of the Society have played in the construction of modern science and are a welcome corrective to the all-too-common popular perception of Jesuits as reactionary zealots. It seems that Jesuit science may soon surpass intercultural exchange as the hottest topic in Jesuit studies.

Analyzing the bibliographical data contained in the Nso does more than identify current trends. It also reveals which areas are understudied and therefore ripe for additional research. Take for example the distribution of citations by continent. During the period of 2011-13, over fifty percent of geographic references were to Europe. Asia, North America, and South America each accounted for around fifteen percent, with Asia leading the way due in no small part to recent interest in Ricci and the China mission. Very little attention has been paid to Africa, however, despite a not wholly insignificant Jesuit presence there. Similarly, India has been relatively neglected: while China was listed as a subject in nearly four hundred citations, there were only sixty items

$5^{6}$ Claudia Brosseder, The Power of Huacas: Change and Resistance in the Andean World of Colonial Peru (Austin: University of Texas Press, 2014); Raphael Brewster Folsom, The Yaquis and the Empire: Violence, Spanish Imperial Power, and Native Resilience in Colonial Mexico (New Haven, ст: Yale University Press, 2014); Robert Michael Morrissey, Empire by Collaboration: Indians, Colonists, and Governments in Colonial Illinois Country (Philadelphia: University of Pennsylvania Press, 2015).

57 Luis Enrique Ramos Guadalupe, Father Benito Viñes:The 1 $^{\text {th }}$-Century Life and Contributions of a Cuban Hurricane Observer and Scientist, trans. Oswaldo García (Boston: American Meteorological Society, 2014); Roberto Buonanno, The Stars of Galileo Galilei and the Universal Knowledge of Athanasius Kircher (Cham, Switzerland: Springer, 2014); Francisco Malta Romeiras, Ciência, prestígio e devoção: Os jesuítas e a ciência em Portugal (séculos $X I X$ e XX) (Cascais, Portugal: Lucerna, 2015); Christopher M. Graney, Setting Aside All Authority: Giovanni Battista Riccioli and the Science against Copernicus in the Age of Galileo (Notre Dame, IN: University of Notre Dame Press, 2015); Mark A. Waddell, Jesuit Science and the End of Nature's Secrets (Surrey, UK: Ashgate, 2015); Augustin Udías, Jesuit Contribution to Science: A History (Cham, Switzerland: Springer, 2015); Zhang, Making the New World Their Own. 
related to India. Lately, both situations may have begun to change, as indicated by a new book on Jesuits in Africa and two on the Jesuit presence in India. ${ }^{58}$ Both fields seem primed for further development.

Considering the distribution of entries by time period is also revealing. Nearly half of all references in the 2011-13 dataset are to the sixteenth and seventeenth centuries. This is unsurprising, as they were the centuries of the Society's establishment and expansion and witnessed the launch of its great missionary enterprises. The twentieth century is also well represented, at twenty percent, thanks to the continued influence and relevance of modern Jesuit theologians such as Lonergan and Rahner. In comparison, the eighteenth and nineteenth centuries are rather understudied, as together they are referenced in only a quarter of NSO citations. The nineteenth century in particular has received very little attention. This seems to indicate another promising direction for future research, since the era was that of the order's suppression and restoration. Indeed, there has already been some movement in that direction: Brill recently published a book on Jesuit Survival and Restoration, ${ }^{59}$ based on a conference held at Boston College in the summer of 2014, and Cambridge University Press is about to follow suit with a collection of its own. ${ }^{60}$

The foregoing analysis illustrates the enormous value of a resource like the $N s o$. Jesuit studies is clearly a dynamic and rapidly expanding field. New scholars entering it need a way to quickly orient themselves to the existing literature, and researchers in related fields need a way to locate points of intersection between Jesuit studies and their own areas of expertise. Jesuits can use the bibliography to gain a better understanding of their organizational history, and even casual readers can use it to identify the highlights of a new and exciting academic discipline. The wealth of information contained in the $N S O$ provides not just an overview of the current state of Jesuit studies but a roadmap for its future.

$5^{8}$ Andreu Martínez d'Alòs-Moner, Envoys of a Human God: The Jesuit Mission to Christian Ethiopia, 1557-1632 (Leiden: Brill, 2015); Pamila Gupta, The Relic State: St. Francis Xavier and the Politics of Ritual in Portuguese India (Manchester, UK: Manchester University Press, 2014); Ângela Barreto Xavier and Ines G. Županov, Catholic Orientalism: Portuguese Empire, Indian Knowledge (16th-18th Centuries) (New Delhi: Oxford University Press, 2015).

59 Robert A. Maryks and Jonathan Wright, eds., Jesuit Survival and Restoration: A Global History, 1773-190o (Leiden: Brill, 2014).

6o Jeffrey D. Burson and Jonathan Wright, eds., The Jesuit Suppression in Global Context: Causes, Events, and Consequences (Oxford: Oxford University Press, 2015). 


\section{A Legacy Renewed}

The publication of Carlos Sommervogel's Bibliothèque de la Compagnie de Jésus was a monumental achievement. Building upon the work of Pedro de Ribadeneyra and his pre-suppression successors, Sommervogel not only completed the resurrection of Jesuit bibliography but brought it to new heights. In the twentieth century, the torch passed to László Polgár, who carried on the great bibliographer's legacy while updating it in accordance with the demands of contemporary scholarship.

The New Sommervogel Online aims to accomplish the same task for a new millennium. By harnessing the capabilities of modern technology and tapping into the potential of global collaborative networks, it is compiling a Jesuitthemed bibliographical database that will be more comprehensive than any that has come before and is making that resource available in an unprecedentedly user-friendly way. The $N s O$ will be an enormous boon for the burgeoning field of Jesuit studies and will bring the venerable tradition of Jesuit bibliography into the digital age. 